\title{
Study on Talents Cultivation of Innovative Entrepreneurial Exhibition from the Perspective of Transformation
}

\author{
Yan Zhu ${ }^{1, \text { a }}$ \\ ${ }^{1}$ Xi'an International University, Xi'an, Shaanxi, 710077 \\ ${ }^{a}$ email
}

Keywords: Talents Cultivation, Innovative Entrepreneurial Exhibition, Transformation

\begin{abstract}
Innovation and entrepreneurship is the basis for the exhibition industry, it is to enhance and develop the fundamental Chinese exhibition industry. How to really improve the quality of education exhibition, cultivate high-quality creative talents has become a hot topic in the exhibition industry. From the status of professional practitioners, this paper studies the vocational training Exhibition lag, the absence of applied sexuality and other issues, combined with industry business line needs and teaching practice, attempts to explore the exhibition to enhance innovation and entrepreneurial talent vocational ability.
\end{abstract}

\section{Introduction}

Along with Chinese higher education from elite education to change the education system of mass education are constantly reform and deepen. In order to meet the needs of social development, Chinese institutions of higher learning and gradually form a variety of training model. By foreign experience in higher education, we can see that the school-enterprise cooperative training of personnel is the world's countries, especially a major trend in education reform and development in developed economies, education and industrial economy combined with effective training applied talents way. In China, since the reform and opening up, school-enterprise cooperative training model of colleges and universities have formed a variety of platforms, multi-mode and common development trend. Only companies and universities to participate in personnel training in order to improve the educational status of the theory and practice divorced from current college graduates in school. School-enterprise cooperative training model has become the educational reform and theoretical study based on hot spots. School-enterprise collaboration is the main path complex, application-oriented, highly qualified senior specialized talents. Some Chinese colleges and universities have begun to some extent, to carry out school-enterprise cooperative training model. Some colleges and universities have made in this regard a significant achievement, but most colleges and universities in the process of school-enterprise cooperative personnel training is still in its infancy, there is no deeper development. Many colleges and universities to build long-term stable and do not realize the importance of school-enterprise cooperative entrepreneurship training system innovation. Only by establishing school-enterprise collaborative innovation and entrepreneurship training system in line with the law of development of talents to train various types of personnel to adapt to social development.

\section{Innovative Entrepreneurial Talent Exhibition Features}

Innovation and entrepreneurship refers to the subject of education as the base, with a good general knowledge base, comprehensive quality, professional suitability for the tower to innovative and entrepreneurial capacity of the spire, to suit the requirements of the future development of high-quality talents. Their comprehensive quality and ability mainly is in four aspects.

On the structure of knowledge, innovation and entrepreneurial talent necessary to master the latest research results and trends, but also to understand the neighboring disciplines of knowledge, with good science and humanities related to finance, management, social skills, requires a solid foundation, development enough stamina, expertise complete the system. Only with a broad range of basic theoretical knowledge is in order to better to put it into practice. MICE professional 
education in the process, should rely on the basis of the core theory of management, economics and other basic subjects, settings management, marketing, public relations, sociology, economics, advertising and other courses, so students theoretical basis of the exhibition solid, profound knowledge become generalists.

Innovation and entrepreneurial talent than the general application of talent wider range of knowledge, wider field of vision, with more practice, innovation and entrepreneurship. Good practice refers to the ability to identify problems and problem-solving, innovation refers to the integrated use of existing knowledge, creatively put forward new discoveries, new inventions and new programs. The ability to grasp the business opportunities is including, planning decisions, create a team, marketing, management, financial management, risk management capabilities. Develop these comprehensive capabilities related to specific operations, teaching is difficult, but also the weaknesses of university education, difficult to evaluate, need to strengthen.

Innovation is the Venus of entrepreneurial activity. In entrepreneurial activity, the need for innovative thinking, and constantly come up with new solutions to new problems. Maslow has proposed training "a brand new person," "He can go with the flow, can change for the music, to create ad hoc, can confidently, strength and courage to go against him unprepared sometimes faced with situations." This species creativity permeates the entire human life and become a personality or quality. MICE should strengthen students' sense of innovation and cultivate innovative thinking, stimulate their entrepreneurial initiative and entrepreneurship has impulse and passion, perseverance, until it succeeds.

In addition to a sound personality and a good psychological quality, the innovation and entrepreneurial talent must have good IQ and EQ. In the entrepreneurial process, closely related to the quality of knowledge and skills in the use of personal psychological, moral and other aspects of the non-professional; innovative entrepreneurial application of talent must have basic professional morality, but also have a realistic approach, critical spirit, tenacity will, initiative, responsibility, teamwork, innovative thinking, curiosity, strategic vision and overall concept and the like.

\section{Exhibition Talents Situation Analysis}

On the one hand, from higher vocational colleges is MICE Talents current situation. First, positioning is not accurate in the exhibition talent cultivation. Or positioned too high, in line with the colleges, focusing on teaching the theory; or positioning deviation is not in line with market supply and demand for exhibition personnel competence requirements. Secondly, personnel training programs under development is application of the concept of lack of culture, the absence of practical aspects, leading to a lack of hands-on exhibition of talent and innovative ability. Finally, on the course design and teaching, conservative, whether institutions or the teachers themselves can not be effectively based on professional characteristics of teaching reform and innovation. Thus cultivate the knowledge structure is not far from the system, and the practical ability is far below the industry standard enterprise. On the other hand, from higher vocational colleges MICE Talent Employment Situation of view exhibition of 2013 for school planning and management graduates employment status of an investigation. From the feedback situation, employers believe that colleges and universities in the professional training process, there is talent and professional competence is not accurate positioning, not systematic theoretical knowledge, practical ability and lack of other issues, companies are less satisfied with the professionals. Wherein MICE Majors positioning capability, 83 percent of employers believe that the current exhibition personnel are most in need and lack of communication skills and practical ability, and poor students' innovation and learning ability, comprehensive quality and industry business needs far cry.

\section{Cultivation Method of the Exhibition Talents}

The rapid development of exhibition industry, the face of new situation and new problems, the government needs to provide theoretical support scholars in universities and solutions. Research is an important form of government and universities to interact. College Teachers bear horizontal 
issues for government departments and enterprises to solve problems, but also to enhance their professional level of research, to deepen understanding of the exhibition industry, the exhibition accumulation of teaching vivid cases. As a link to the topic, universities and government communicate frequently, to lay the foundation for both the depth of cooperation. Second, the Government's commitment exhibition projects and when universities and government cooperation, we can be used "to finance the project but also to" strategy. Financial support just once or twice, can not last long. If the government can continue to receive fair project and can effectively improve the ecological education College exhibition, in fact, also received financial support. Through government commitment exhibition project, teachers will be the latest industry information into the classroom to make the classroom a more vibrant and vivid.

Exhibition Association is the exhibition business polymers, held many exhibition projects and it requires a lot of exhibition personnel. University Students need internship opportunities for professional practice passionate, good human resources. However, universities and companies often asymmetric information, the two can build interactive mechanisms to effectively implement internship demand docking. Universities can be established at the Convention internship base, and build a set of student internships, teacher training and student employment as an integrated platform. Second, establish a system of exchange visits between schools and enterprises to strengthen exchanges and cooperation. MICE business combined with job requirements, together lesson plans, arrangement of teaching content. Universities invited to participate in the industry elite training quality evaluation of school personnel, student employment and development of follow-up survey, to make an objective assessment of the quality of teaching. The third is to hire the exhibition business elite for university professor. Most colleges and universities MICE established, teachers weak, only a small number of people, and the lack of practical experience in the industry, through "skills, please come in and go" approach to strengthening teacher team building. "Please come in" to request the industry elite to enter the campus, ask them to train full-time teachers, lectures, undertake the task of teaching, guiding students internships, cooperation with the university teachers in academic research, guidance of professional development.

School educational background and targeting different and distinctive teaching practice. Some large-scale organized study tours, broaden students' horizons; some established schools Convention Center, conducted alternately teaching engineering activities; some combination of local exhibitions, organizing internships students suspended, as an alternative to classroom instruction; some schools were still groping, yet to find an effective way. Low-grade students to business and exhibition venues as volunteers, to carry out awareness practice is necessary, but high school students to volunteer enthusiasm is not high; large-scale outside school trips, school leaders and teachers pressure, students and parents also have resistance. In addition, the school funding tight is hoping to create a good campus environment, campus security office for strict control.

This requires teachers and in-depth research, a comprehensive consideration of the project why do they need? What are the risks? Project to "indomitable spirit" is meaningful, tall, and can rely on the existing campus resources and conditions easy to achieve, ground gas, to attract media attention and coverage, resulting in widespread social impact. Such a practice is not to do the project done, but to learn by doing, not only focus on results, more emphasis on process, teachers and students get experience and growth in participation. In the Internet era, the practice of teaching activities to the pursuit eye effect; teachers and students are very valuable time and energy, not wasted on futile activity.

Continue to promote school-enterprise cooperation to diversify forms of school-enterprise cooperation, more thinking, the angle. Not only for students to build a platform for business practices, while also providing the opportunity to learn and practice into the business line for teachers to enrich their professional reserve. It can also be included in class business practices that directly involved in front-line experts in teaching, so that the corporate sector the latest ideas and information to students, to avoid loss of information and variation.

Actively explore various forms of learning. Try the student, between different grades establish old and new mechanisms. Such as the three-year students set up their own team, the exhibition 
business simulation project execution process. Conditions can be led by teachers in cooperation with enterprises, providing front-line services.

Training focused on application-oriented exhibition personnel that application, namely to enhance the training and practice ability. This requires that institutions and teachers to encourage and support students to explore various forms of independent types of activities, such as running the school on various topics exhibition, University Union touring exhibitions. Note that in the simulation while focusing normative. This requires teachers to give appropriate guidance and help, and ultimately in the "learning by doing" teaching mode.

\section{Conclusion}

Student innovation and entrepreneurship education is a systematic project. It is related to higher education trained talents has innovative entrepreneurship or not. It is able to adapt to the development of today's society and economy. It is able to assume the revitalization of the national cause. It requires government schools and society work together. We need to advance theory. Need more practice norms to encourage them to create personal wealth at the same time, create jobs for the community. Promote social and economic development.

\section{Acknowledgements}

Project in 2016 of Shaanxi Province Education Science "Thirteen Five" plan.

\section{References}

[1] Thomas A S, Mueller AL. A Case for Comparative Entrepreneurship; Assessing the Relevance culture [J]. Journal of International Business Studies, 2000, (31):66.

[2] The First Sino-US Innovation and Entrepreneurship Summit of Carnegie Mellon University Held in Pittsburgh [J].Chinese Foreign Trade, 2012, (06):59.

[3] Ming Sun, Jun Zhang, Jun Dong, Bing Chang. Cdio based Optimization of Urban Planning Personnel Training Courses in Forestry Universities [J]. Asian Agricultural Research, 2014, (09):81-84.

[4] Christine Chryton. Assessing General Creativity and Creative Engineering Design in Engineering Students [J]. JEE, 2009, (13):45.

[5] Semra Guven. World Conference on Educational Sciences 2009 New Primary Education Course Programme and Entrepreneurship [J]. Social and Behavioral Sciences, 2009, (01):265. 